\title{
Multi-symptom asthma as an indication of disease severity in epidemiology
}

\author{
Linda Ekerljung ${ }^{1}$, Apostolos Bossios ${ }^{2}$, Jan Lötvall ${ }^{2}$, Anna-Carin Olin³ ${ }^{3}$ Eva Rönmark ${ }^{4}$, Göran Wennergren ${ }^{5}$, \\ Kjell Torén ${ }^{3}$, Bo Lundbäck ${ }^{2^{*}}$
}

\author{
From EAACI International Severe Asthma Forum (ISAF 2012) \\ Gothenburg, Sweden. 11-13 October 2012
}

Epidemiological questionnaires have failed to identify individuals with severe asthma. The extent of symptoms of asthma can, however, easily be established in epidemiological studies by identification of multiple symptoms. We hypothesized that reporting of multiple symptoms of asthma reflects uncontrolled disease and can be a sign of more severe asthma. The aims of the current study were, therefore, to determine the prevalence and determinants of multi-symptom asthma. In this paper we report our definition of multi-symptom asthma and its clinical characteristics. A postal questionnaire was mailed to 30,000 randomly selected subjects aged $16-75$ yrs. A subgroup underwent detailed clinical examinations including lung function test, exhaled NO, methacholine test in addition to a detailed clinical history by using structured interview. Multi-symptom asthma was defined as questionnaire reported physician-diagnosed asthma, use of asthma medication, recurrent wheeze, attacks of shortness of breath, and at least one additional respiratory symptom. The overall prevalence of physician-diagnosed asthma was $8.3 \%$, while of multi-symptom asthma the prevalence was $2.0 \%$ (women $2.4 \%$, men $1.5 \%, \mathrm{p}<0.001$ ). Multi-symptom asthma versus other asthma was associated with lower FEV1 (88.8\% pred vs. $98.8 \%$ pred), higher FeNO (29.3 ppb vs. $23.2 \mathrm{ppb}$ ), a greater proportion having PD20<1.96 mg methacholine chloride ( $82.9 \%$ vs. $58.7 \%)$, all statistically highly significant. The same pattern was found for asthma exacerbations, emergency department visits and hospitalizations. All respiratory symptoms were more common in multi-symptom asthma compared with other asthma, and that was true also for symptoms of bronchitis, rhinitis and rhino-sinusitis. In contrast, allergic rhinitis and allergic sensitization were not more common in multi-symptoms

2University of Gothenburg, Institute of Medicine/Krefting Research Centre, Sweden

Full list of author information is available at the end of the article asthma than in other asthma. Multi-symptom asthma cannot be used for defining severe asthma. We conclude, however, that multi-symptom asthma, as we defined the condition, is related to signs of more severe disease and could be used as an epidemiological marker of asthma severity.

\section{Author details \\ ${ }^{1}$ University of Gothenburg, Sweden. ${ }^{2}$ University of Gothenburg, Institute of Medicine/Krefting Research Centre, Sweden. ${ }^{3}$ University of Gothenburg, Institute of Medicine/Dept of Occup \& Envir Med, Sweden. ${ }^{4}$ University of Umeå, Dept of Public Health \& Clinical Medicine, Sweden. ${ }^{5}$ University of Gothenburg, Dept of Pediatrics, Sweden.}

Published: 3 May 2013

doi:10.1186/2045-7022-3-S1-P6

Cite this article as: Ekerljung et al:: Multi-symptom asthma as an indication of disease severity in epidemiology. Clinical and Translational Allergy 2013 3(Suppl 1):P6.

Submit your next manuscript to BioMed Central and take full advantage of:

- Convenient online submission

- Thorough peer review

- No space constraints or color figure charges

- Immediate publication on acceptance

- Inclusion in PubMed, CAS, Scopus and Google Scholar

- Research which is freely available for redistribution

Submit your manuscript at www.biomedcentral.com/submit
C Biomed Central

() 2013 Ekerljung et al; licensee BioMed Central Ltd. This is an Open Access article distributed under the terms of the Creative Commons Attribution License (http://creativecommons.org/licenses/by/2.0), which permits unrestricted use, distribution, and reproduction in any medium, provided the original work is properly cited. 